currents, produce plentiful rainfall, with its consequent forest growth. Along the Chinsha, Yalung and Tatu Rivers are rich warm valleys. The wide range of climatic and geographical conditions makes it favourable as habitation for a great variety of species.

Another factor is the region's geological age. The north-south ranges of western Szechuan are believed to have been established during the last stage of the Pleistocene period, which makes them older than the Himalayas, with which they are contiguous. The mountains seem to have afforded asylum for many primitive types of mammals, including the giant panda, the lesser panda, the golden monkey, the Szechuan jumping mouse and the common Chinese zokor.

The third factor is that the region lies at a latitude where the Palæarctic and the Oriental of the world's zoogeographical regions meet, with the north-south mountain ranges serving as a kind of corridor for the mammals of the two regions. Contact of the northsouth ranges with the east-west Himalayas and Kunlun allows a certain interchange or extension of range for some of the faunal elements.

\title{
OBITUARIES
}

\section{Dr. S. T. Ma}

THE death occurred in Sydney on January 27, 1962, of Dr. Shih Tsun Ma, senior lecturer in theoretical physics in the University of Sydney.

Dr. Ma was born in Peiping, China, on June 29, 1913. He attended the National University of Peking, first as a student and then on the staff, during 1929-37, obtaining his B.Sc. degree in 1935 . From 1937 until 1941 he was a postgraduate student of Queens' College, Cambridge, obtaining his Ph.D. degree in 1941. During this period he worked under and was deeply influenced by Prof. P. A. M. Dirac.

He was then appointed professor in the physics department of his old University, the National University of Peking, and held this position during 1941-45. During this period two of his students were C. N. Yang and T. D. Lee, destined themselves to become distinguished theoretical physicists. In 1945, Dr. Ma left China to become a member of the School of Mathematics, the Institute for Advanced Study, Princeton, where he stayed for two years; he spent the succeeding two years $(1947-49)$ as a scholar in the School of Theoretical Physics, Dublin Institute for Advanced Studies, and the next two years again (1949-51) as a post-doctorate Fellow in the Institute for Nuclear Studies, University of Chicago. During this time he married Mrs. Helen Lin, secretary to Prof. Enrico Fermi. In 1951 he took up a post-doctorate fellowship with the National Research Council of Canada, Ottawa. Finally, in 1953, he joined the Theoretical Physics Department of the School of Physies, University of Sydney, as a lecturer, to be soon promoted to senior lecturer, which position he held until his death at the age of fortyeight years. His stay of almost eight years in the University of Sydney, broken only by a sabbatical study leave in 1960 and spent at the University of Cambridge, was his longest stay in any one place in the Western world.

Dr. Ma's first scientific article, "Variational Wave Functions of Doubly Excited States of Helium", was published, in collaboration with $\mathrm{T}$. Y. Wu, in the Journal of the Chinese Chemical Society in 1936. After several such publications in Chinese journals his first article in a Western journal was "Photomagnetic Disintegration and Magnetic Moment of the Deuteron in the Meson Theory", published in the Proceedings of the Cambridge Philosophical Society, 1940. During the ensuing years his thirty-five scientific papers found global distribution in the world's scientific journals; most of these were devoted to subjects in quantum electro-dynamics or meson field theory.
Staff and students alike in Sydney knew Dr. Ma not only as a research leader but also as a man devoted to his work and who prepared and delivered his lectures with meticulous care and a thoroughly sympathetic comprehension of student problems. By his unobtrusive manner and quiet sense of humour he endeared himself to all with whom he came in contact. Dr. Ma's life was obviously influenced by the teachings of Confucius and the ancient Chinese love of learning and devotion to duty. The rigid rules-self-imposed -to which he forced himself to subscribe included the beliof that a day is wasted when something is not added to one's store of knowledge. His sole ambition was to contribute to man's scientific knowledge and understanding; it is thus fitting that his contributions to physics should form the monument to Dr. Shih Tsun Ma.

He is survived by his widow and stepson Kenney. S. T. Bortwr

\section{Prof. Gabriel Bertrand}

Prof. G. Bentrand, who was approaching the age of a hundred, passed away at Paris on June 20, 1962. He was a professor of biochemistry in the Pasteur Institute, Paris, from 1908. There he worked extremely systematically and regularly for sixty years.

During the First World War, I followed his lectures and it was known at that time that Prof. Bertrand advised the French War Office to introduce gas warfare by the application of chlorine. The Germans took possession of his Laboratory during the Second World War, when Prof. Bertrand continued his researches.

$\mathrm{He}$ was an extremely gentle and kind man. $\mathrm{He}$ created a large School of Biochemistry. He was a versatile research worker and a pioneer in several lines of investigations. This is indicated in the Bertrand Medal, when the following lines occur:

"Venin and vaccination and anti-venin, cellulose and wood, sugars, Sorbose bacteria, lac, laccase, oxydases, diastases and co-diastases, manganese and infinitely small amounts of catalytic chemical fertilizers (trace elements), biocatalysts, chloropicrin, destruction of parasites, etc. ..."

Prof. Bertrand by his research work established that plant growth and health do not depend only on carbon, nitrogen, oxygen, hydrogen, soda, phosphorus, potash, lime and sulphur, but also on a host of other elements like manganese, iron, copper, zinc, cobalt, boron, iodine; even rubidium and cæsium are present in the plant ash. 